\title{
The role of concentrations gradients on phosphorus and iron dynamics from chemically- dosed horizontal flow wetlands for tertiary sewage treatment
}

\author{
Jan Barak ${ }^{\mathrm{a}}$, Gabriela Dotro ${ }^{\mathrm{a}}{ }^{*}$, Bruce Jefferson $^{\mathrm{a}}$ \\ ${ }^{a}$ Cranfield University, College Road, Cranfield, Bedfordshire, MK43 OAL, UK. \\ *corresponding author: g.c.dotro@cranfield.ac.uk
}

\begin{abstract}
This study examined the dynamics of iron (Fe) and phosphorus (P) transformations from the surface sludge accumulated in tertiary horizontal flow (HF) treatment wetlands (TW) chemically dosed for P removal. Site surveys showed $\mathrm{P}$ was stored in HF TW with and without artificial aeration on average, with instances of $\mathrm{P}$ release in the non-aerated site. Controlled experiments revealed storing TW surface sludge for over 24 hours resulted in limited oxygen and nitrate concentrations, resulting in both $\mathrm{P}$ and Fe release. The rate of $\mathrm{P}$ release increased with increasing water-sludge $\mathrm{P}$ concentration gradients, and the reaction could take as little as ten minutes. Convection had no impact on $\mathrm{P}$ transformation rates. The findings suggest mitigation strategies could include the manipulation of the biogeochemical environment by managing oxygen and nitrate concentrations within the wetlands. A better understanding of links between $\mathrm{Fe}, \mathrm{P}$, and nitrate is needed to test proactive mitigation strategies for small wastewater treatment plants.
\end{abstract}

Keywords: aerated wetlands; diffusion; nitrate; reed beds; wastewater.

\section{INTRODUCTION}

The need to manage nutrient discharges into natural water bodies has been recognised worldwide for years, with increasingly more countries setting tighter target maximum 
concentrations of phosphorus $(\mathrm{P})$ and nitrogen concentrations in rivers. This has resulted in "point sources" of polluting discharges like domestic wastewater treatments plants (WWTPs) being required to remove more nutrients, as these can contribute significantly to phosphorus concentrations in streams (Neal et al., 2010). As the need for delivering better treated effluents increases so do the pressures on municipalities and water utilities to meet them at the minimum financial and environmental costs. Within this context, it is becoming increasingly important to maximise the assets' life at domestic WWTPs by retrofitting the treatment units to meet new demands without replacing the existing infrastructure. For rural works serving less than 2,000 population equivalents, this has been successfully achieved in many cases by installing artificial aeration for ammonia removal within existing tertiary HF wetlands (Butterworth et al., 2013), flooding parts of vertical flow (VF) wetlands for total nitrogen removal (Prigent, Paing, et al., 2013), and adding chemical dosing upstream of the biological stages in a WWTP (Brix and Arias, 2005; Dotro et al., 2015; Lauschmann et al., 2013). However, the risks associated with the additional treatment functions are poorly understood (Butterworth et al., 2016; Dotro et al., 2015).

Phosphorus removal is commonly achieved through the addition of aluminium or iron (Fe) based salts. Iron traps phosphorus directly, by precipitating as ferric phosphate in aerobic, turbulent conditions; or indirectly, by providing adsorption sites on iron hydroxide precipitates' surfaces (Thistleton et al., 2002), both of which are settled out or trapped in physical filters prior to discharge to the water course. The entrapment of phosphorus and iron in this manner is believed to be irreversible under storage and desludging conditions in conventional, large WWTP (e.g., hours or days). In the UK, HF wetlands have been used as a tertiary treatment step for the removal of organic matter (measured as biochemical oxygen demand; BOD) and suspended solids (TSS) for over 25 years. Treatment wetlands as tertiary solids filters, thus, are 
believed to provide an additional benefit when Fe dosing is incorporated, as they should provide a barrier for trapping particulate Fe and $\mathrm{P}$. However, $\mathrm{P}$ release has been observed in some systems, primarily related to seasonal variations in systems with very low $\mathrm{P}$ inputs and no harvesting (Headley et al., 2003) and anaerobic conditions (Dotro et al., 2015; Kim et al., 2015). Water table fluctuations have long been known to influence Fe speciation, with release occurring under flooded conditions and storage of Fe under drained (oxic) conditions (Reddy and DeLaune, 2008). Typical flowsheets for rural WWTPs incorporate one or more stages of solids settling and storage, either before or after biological treatment processes. Storing sludge in-situ for extended time (i.e., months for settling units, decades for TWs) provides opportunities for anaerobic conditions to develop. A better understanding of $\mathrm{P}$ and Fe cycling is needed to develop the strategies to mitigate their risk of periodic release.

Phosphorus release from iron-containing solids is intricately linked to Fe use as a terminal electron acceptor (TEA) by facultative microorganisms. There are defined redox profiles for the step-wise biological utilisation of dissolved oxygen (DO), nitrate $\left(\mathrm{NO}_{3}\right)$, and Fe as TEAs for the oxidation of organic matter in the natural environment, with nitrate providing $95 \%$ and iron only giving $20 \%$ of the aerobic energy yield (Reddy and DeLaune, 2008). In conventional WWTP, minimum DO levels to achieve Fe storage have not been defined but they typically operate above $1 \mathrm{mg} / \mathrm{L}$ to enable complete nitrification ((Dotro et al., 2011)), which is believed to be sufficient to keep Fe oxidised and P trapped. Minimum nitrate levels that would result in storage are also undefined for this context, but based on the energy yields it has been assumed that as long as "excess" nitrate is present, Fe will not be used by microorganisms and result in P storage. However, on a site surveyed before and after the removal of surface sludge and replacement of the top $5 \mathrm{~cm}$ of media of a tertiary HF wetland, release was observed under effluent concentrations of $16 \mathrm{mg} \mathrm{NO}_{3} / \mathrm{L}$ but not under concentrations of $9 \mathrm{mg} \mathrm{NO} / \mathrm{L}$ 
(Dotro et al., 2015). The main differences between the two sampling campaigns were a) surface sludge accumulation mass, and b) influent concentration of $0.5 \mathrm{mg} \mathrm{TP} / \mathrm{L}$ under instances of $P$ release compared to $1.8 \mathrm{mg} T \mathrm{~T} / \mathrm{L}$ influent concentration under instances of $\mathrm{P}$ storage (Dotro et al., 2015). This suggests the transfer of TP and Fe between solid (sludge) and liquid (wastewater) phase is influenced by the concentration gradients developed between the two phases. Whilst not a risk to compliance when trying to meet effluent targets of 1-2 mg $T P / L$, this can become critical for applications in the low $\mathrm{P}$ levels expected to come in force based on the Water Framework Directive challenge. There is a clear need to better understand the processes responsible for $\mathrm{P}$ storage and release, within the wider framework of considering whole system when upgrading assets to meet future consents. This paper aims to explore the impact of concentration gradients on Fe and P release from chemically-dosed tertiary HF TW surface sludge. Site surveys were conducted at two tertiary HF wetlands in the Midlands region of the UK that had similar design and loading rates, one retrofitted with artificial aeration and one kept unaerated. This was used to assess the impact of operating conditions (i.e., $\mathrm{DO}, \mathrm{NO}_{3}$ ) in constructed wetlands on $\mathrm{P}$ and Fe dynamics. Controlled tests were used to elucidate the impact of water TP starting concentration and diffusion on Fe and P storage and release.

\section{METHODS}

\section{Field survey}

Two WWTPs owned and operated by Severn Trent Water were selected for the survey based on similarities in design (sizing criteria, flow rates), upstream treatment processes, and proximity (which affects climate). The first site consisted of a packaged integral rotating biological contactor (RBC) with primary septic tank and final settling tank incorporated within the same physical structure, followed by two parallel combined tertiary HF wetlands each 182 
$\mathrm{m}^{2}$ in plan area filled with $0.6 \mathrm{~m}$ of gravel. The HF beds received nitrified effluent from the upstream RBC and were kept unaerated, thereby conditions were expected to be anoxic (i.e., oxygen poor but nitrate rich). The site was designed to meet a $40 \mathrm{mg} / \mathrm{L}$ carbonaceous, 5 -day BOD (referred to as BOD thereafter for simplicity), $60 \mathrm{mg} / \mathrm{L} \mathrm{TSS}, 2 \mathrm{mg} / \mathrm{L} \mathrm{TP}$, and $4 \mathrm{mg} / \mathrm{L}$ total Fe. The second side had a similar flowsheet (RBC+HF wetland) but was retrofitted with artificial aeration a year prior to the study commencing, ensuring the wetland was aerobic throughout. The site consisted of a single integral RBC followed by a single $419 \mathrm{~m}^{2}$ aerated constructed wetland, with the same gravel depth of $0.6 \mathrm{~m}$. The RBC was sized to treat $267 \mathrm{~m}^{3} / \mathrm{d}$, with flows in excess of this bypassing the unit. When in operation, the bypassed flows were treated with soft mesh screenings (Copasacs ${ }^{\mathrm{TM}}$ ) and mixed with the secondary treated water at the influent of the wetlands. The site has to meet a discharge standard of $25 \mathrm{mg} / \mathrm{L} \mathrm{BOD}, 45 \mathrm{mg} / \mathrm{L} \mathrm{TSS}, 15$ $\mathrm{mg} / \mathrm{L}$ ammonium as nitrogen $\left(\mathrm{NH}_{4}-\mathrm{N}\right), 2 \mathrm{mg} / \mathrm{L} \mathrm{TP}$, and $4 \mathrm{mg} / \mathrm{L} \mathrm{Fe}$. Both sites received flowproportional dosing of ferric sulphate $\left(\mathrm{Fe}_{2}\left(\mathrm{SO}_{4}\right)_{3}, 12.5 \% \mathrm{w} / \mathrm{w}\right)$ at the inlet of the biozone, dosing at a ratio of 3:1 (Fe:P) based on expected diurnal influent profiles. The anoxic site was sampled twice: once in the summer of 2012, when the bed had $3 \mathrm{~cm}$ of surface sludge, and in the summer of 2013, a year after the surface sludge was removed. Summer campaigns were selected based on historic records from the water utility on the sporadic release events observed during the operation of conventional (unaerated) tertiary HF wetlands. Further details on the comparison of this site can be found in (Dotro et al., 2015).

Wastewater samples were collected over a period of five (anoxic wetland site) and three (aerobic wetland site) consecutive weeks at the influent and effluent of the wetlands using time-proportional composite sampling. Dedicated autosamplers (ISCO 3700; Teledyne Isco, UK) were set up to collect $100 \mathrm{~mL}$ of sample each hour during 24 hours. Surface sludge was collected from three inlet point along the width of each wetland, where most of the $\mathrm{P}$ and $\mathrm{Fe}$ 
accumulate through settling, by digging with a plastic trowel and storing into 1-L plastic opaque containers. Water samples were transported to laboratory within 2 hours and kept refrigerated $\left(4^{\circ} \mathrm{C}\right)$ until analysis took place. Separate sludge samples were preserved by drying at $40^{\circ} \mathrm{C}$ until achieving constant weight and stored in plastic containers at room temperature before being processed for total Fe and P content.

At the time of sampling, wastewater temperature, redox potential (Eh), $\mathrm{pH}$, and $\mathrm{DO}$ were measured at the two sampling points using an HQ40d portable Meter, DO IntelliCAL LDO105 probe, pH IntelliCAL PHC10101 standard gel filled probe, and gel filled ORP/Redox Probe MTC10101, all manufactured by Hach (Hach, UK). For wastewater temperature the sensor incorporated in the DO probe was used. In addition, the above parameters were measured on a random day of the sampling campaign on-site within each wetland in a $3 \times 3$ grid (length $x$ width). Measurements were made $10-15 \mathrm{~cm}$ below the water surface. Average daily flow rates were obtained from Severn Trent Water records for the corresponding sampling days.

\section{Phosphorus and iron transformations under controlled conditions}

Fresh surface sludge and influent wastewater (i.e., secondary treated effluent) was obtained from the anoxic site and transported to the laboratory for controlled experiments. Both samples were carefully collected to minimise mixing and filled to the top to limit contact with air and sealed hermetically. Samples were stored at $4^{\circ} \mathrm{C}$ until the experiments were started on the day of collection. Chemical and physical characteristics (DO, Eh, EC, pH, temperature) at the time of sampling were measured using previously described apparatus.

To test the effects of water-sludge phosphorus gradients, two types of reactors were set up: test, with a mixture of $0.5 \mathrm{~L}$ sludge and $0.5 \mathrm{~L}$ overlying wastewater; and blank, with $1 \mathrm{~L}$ of 
wastewater (control). The reactors consisted of 1-litre bottles left open to the atmosphere. Five reactors of each type were run in triplicate, each with different initial TP wastewater concentration when mixed with the sludge: $0.1 ; 0.5 ; 1 ; 2$ and $5 \mathrm{mg} / \mathrm{L}\left(R_{0.1}\right.$ to $R_{5}$, respectively). The target TP concentrations were chosen to cover lower as well as higher concentrations than those found typically in secondary effluent. When necessary, the wastewater was spiked with disodium hydrogen phosphate (AnalaR NORMAPUR, UK) or diluted with deionized water to reach the target concentrations. The experiments were run at room temperature (average $20^{\circ} \mathrm{C}$ ). Sampling and filtration took place at time zero $\left(\mathrm{T}_{0}\right) ; 1,2,4$, and 8 hours; and 1,3 and 5 days after $T_{0}$. Sludge was sampled at the start and the end of the experiment from all individual test reactors. Sludge $\mathrm{P}$ and Fe content was 39 and $85 \mathrm{~g}$ of $\mathrm{P}$ and Fe per kg of dry sludge weight, respectively. Samples were processed and analyzed as previously described.

As a second stage, the impact of convection and diffusion on $\mathrm{P}$ and Fe dynamics was tested by running an additional set of reactors, in the same 50:50 ratio of sludge and wastewater as the previous experiment, without any additions to modify initial TP concentrations. Initial sludge Fe and $\mathrm{P}$ content was 38 and $96 \mathrm{~g}$ of $\mathrm{P}$ or Fe, respectively, per kg of dry sludge weight. Two conditions were tested: dynamic and static reactors. For the former, 1-L jars were placed in a jar tester and agitated continuously at 5 rpm (programmable Jar tester PB-900; Phipps \& Bird, UK). The static reactors were run in parallel, without any agitation for the duration of the study. Each condition was run in triplicate and lasted seven days. Wastewater was sampled and filtered with $0.45 \mu \mathrm{m}$ polypropylene non-sterile syringe filter after 1, 2, 4, 6, 8 hours and 1 , 3,5 and 7 days from $\mathrm{T}_{0}$. Probe measurements ( $\mathrm{DO}, \mathrm{pH}$, Eh) were carried out at random intervals directly in the reactors, at $0.5 \mathrm{~cm}$ above the sludge surface and in the middle of the blank reactor. 


\section{Sample processing and data analysis}

The original sample (designated "solution A") containing all suspended, colloidal and dissolved solids was fractionated as described in (Dotro, Fort, et al., 2015). Briefly, suspended particles were removed using a $1.2 \mu \mathrm{m}$ filter paper (Whatman GF/C; GE Healthcare, UK). The filtrate (solution B) contained colloidal and dissolved particles, which were further separated by passing it through low protein binding modified polyethersulfone membranes of $1 \mathrm{kDa}$ pore size (76 mm diameter; PALL Life Sciences, UK) using an Amicon 8400 stirred pressure cell (Millipore UK Ltd, UK), a stirrer (IKAMAG REO; Drehzahl Electonic, UK) and a nitrogen gas supply at the pressure of $10 \mathrm{psi}$. The remaining solution (solution C) was defined to contain only dissolved particles.

All water samples were analysed for $\mathrm{TP}, \mathrm{PO}_{4}-\mathrm{P}, \mathrm{NO}_{3}-\mathrm{N}, \mathrm{BOD}$, chemical oxygen demand (COD), volatile suspended solids (VSS), TSS, $\mathrm{NH}_{4}-\mathrm{N}$, total Fe, $\mathrm{Fe}(\mathrm{II})$, and Fe(III). In addition, the fractionated samples were analysed for TP, $\mathrm{PO}_{4}-\mathrm{P}, \mathrm{Fe}$ total, $\mathrm{Fe}(\mathrm{II})$, and Fe(III). A DR 2800 spectrophotometer, LT 200 thermostat and cuvette test kits (Hach Lange, UK) were used for all analysis, except solids and BOD analysis for which Standard Methods were followed (APHA, 2005). For the latter, nutrient buffer pillows, nitrification inhibitor, an LDO10101 DO probe, and HQ40d meter were employed (Hach lange, UK). Sludge samples were microwave-digested using aqua regia and a Mars 5 Xpress (model 240/50; CEM corporation).

Data were processed by both Microsoft Excel and IBM SPSS Statistics 9 (Version 21) software packages. Correlation analysis using Pearson correlation coefficient and two-tailed test of significance was carried out for the field survey data. A one-way analysis of variance (ANOVA) was used to determine significance of changes in between sampling times for the controlled 
experiments. A mass balance was conducted based on measured liquid phase concentrations and total metal and P content of the sludge at the start and the end of the experiments.

\section{RESULTS AND DISCUSSION}

\section{Phosphorus and iron cycling under field conditions}

Both wetlands were able to positively contribute to the effluent quality by providing the expected removal of solids and organic matter, and ammonia or nitrate, depending on the predominant environment in the beds (see electronic supplementary Information). Influent TP concentrations fluctuated between 0.4 and $2 \mathrm{mg} / \mathrm{L}$, similar to influent total iron levels for both wetlands. Whilst on average both systems retained TP, two out of nine samples in the anoxic site returned effluent TP concentrations equal or slightly higher than its corresponding influent concentration. On examination of fractionation results, total phosphorus was retained in all three fractions in the aerobic wetland whereas the anoxic wetland was able to retain particulate and, to a lesser extent, colloidal TP, but released a small fraction of TP in dissolved fraction (Figure 1a). Nitrate levels in the final effluent were $7 \mathrm{mg} / \mathrm{L}$ and $34 \mathrm{mg} / \mathrm{L}$ for the anoxic and the aerobic wetland, respectively, reflecting their different environment and overall role in the treatment flowsheet for the particular sites. Dissolved oxygen on the top $10 \mathrm{~cm}$ of the beds ranged between $0.1-2.1 \mathrm{mg} / \mathrm{L}$ in the anoxic and $8-10 \mathrm{mg} / \mathrm{L}$ for the aerobic wetland, which corresponded to Eh values of -150 to $+160 \mathrm{mV}$ and +200 to $+330 \mathrm{mV}$ for the anoxic and the aerobic systems, respectively. Iron was trapped in both wetlands, with the exception of one sample in the anoxic site which showed iron release in colloidal form. A greater efficiency was observed for the aerated bed (Figure 1b).

a) 


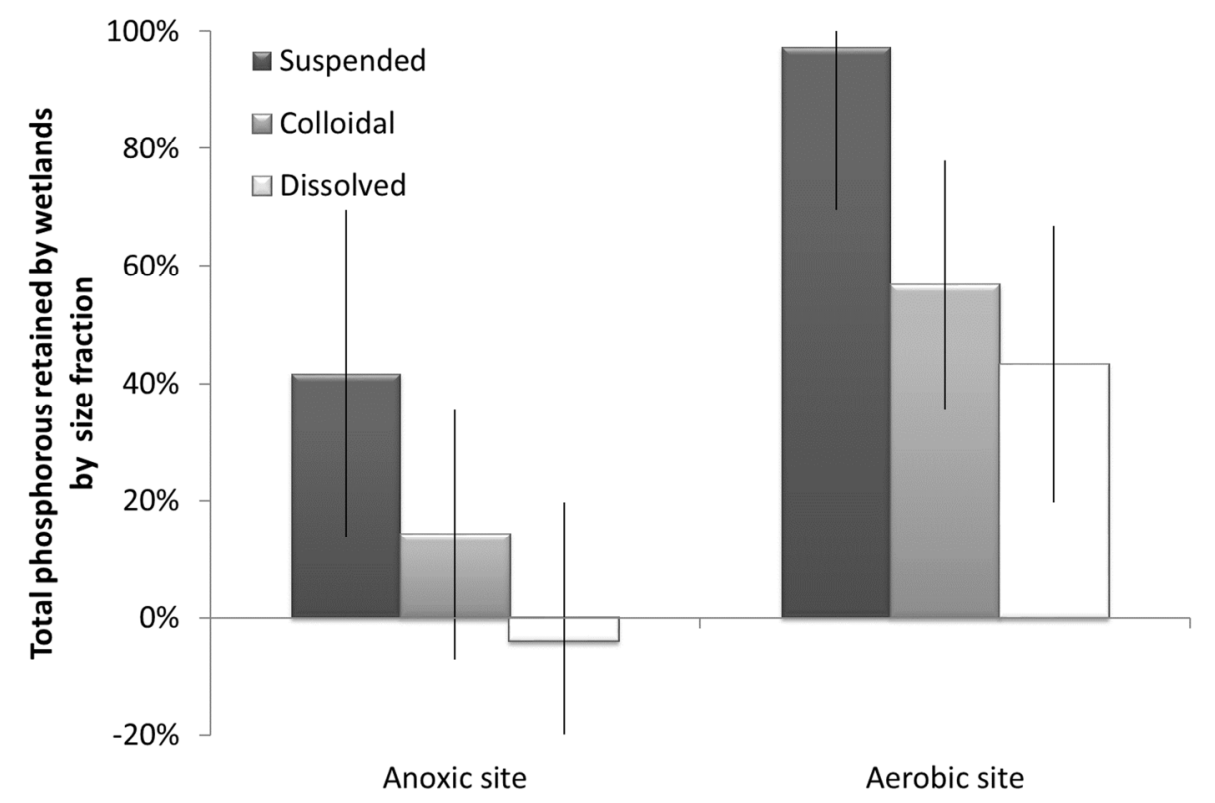

b)

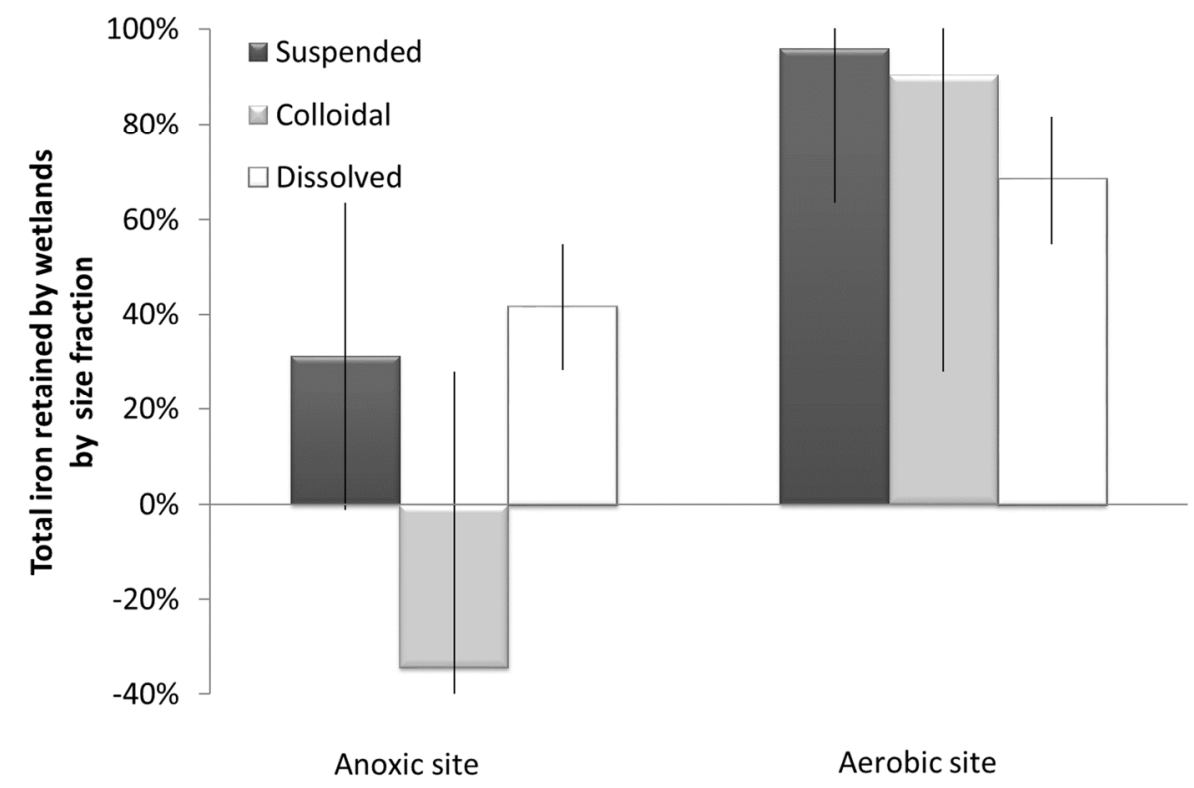

Figure 1. Percentage change from influent to effluent of the anoxic and the aerobic wetlands by size fractionation and pollutant; a) Total phosphorus; b) Total iron.

\section{Phosphorus and iron transformations under controlled conditions}

Impact of initial phosphorus gradient

The control reactors remained at initial values for all parameters measured throughout the experiment, suggesting all changes observed in the test reactors were associated with the 
water-sludge biochemical system. Three apparent stages were identified for all test reactors: an initial transfer of TP from the bulk liquid to the sludge that was complete within 10 minutes of starting the experiments; a second phase, where stabilisation of concentrations appeared to take place, which started at $10 \mathrm{~min}$ after $\mathrm{T}_{0}$ and was completed by $\mathrm{T}_{8}$; and a clear TP release for all reactors which lasted from $T_{8}$ to the end of the experiments (Figure 2).

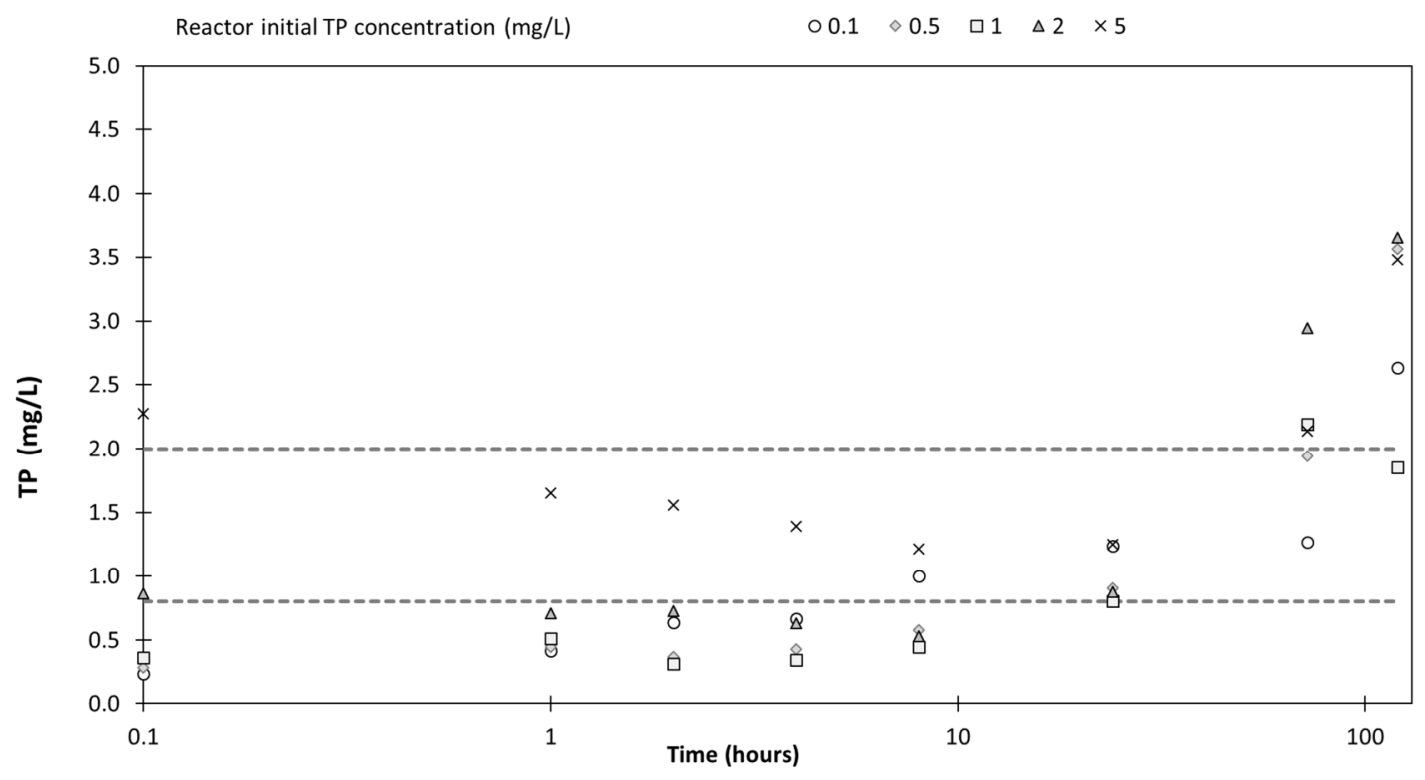

Figure 2. Time progression of total phosphorus concentrations in the liquid phase. Dotted lines represent minimum and maximum TP concentrations measured in the wastewater under field conditions.

In the first ten minutes, the largest shifts in partitioning were observed in the reactors with the greatest concentration difference between the starting point (i.e., target concentrations) and the range of concentrations received in the field by the sampled sludge. Within this first phase, $R_{5}$ had decreased from an initial $5 \mathrm{mg} / \mathrm{L}$ to $2.3 \mathrm{mg} / \mathrm{L}$, which later stabilised around $1 \mathrm{mg} / \mathrm{L}$ of $\mathrm{TP} ; \mathrm{R}_{2}$ had decreased from its initial $2 \mathrm{mg} / \mathrm{L}$ to $0.9 \mathrm{mg} / \mathrm{L}$ within the same time and fluctuated around the same $1 \mathrm{mg} / \mathrm{L}$ average concentrations during the second stage. At the other end of the range, $R_{0.1}$ increased from $0.1 \mathrm{mg} / \mathrm{L}$ to $0.4 \mathrm{mg} / \mathrm{L}$ within the first ten minutes and continued 
to rise to match the normal range of TP concentrations observed in the field. Average TP concentrations at the end of the week were at or above the $2 \mathrm{mg} / \mathrm{L}$ upper limit and were still increasing, suggesting the system remained in a dynamic state.

Impact of competing terminal electron acceptors

Dissolved oxygen and nitrate were depleted in all test reactors to non-detectable levels within four hours of starting the tests. This puts TEA and redox effects in the second phase of the reaction (i.e., between $1 \mathrm{~h}$ and 24 hours of contact) beyond the impact of concentration gradients. Depletion of $\mathrm{DO}$ and $\mathrm{NO}_{3}$ occurred simultaneously, suggesting both TEAs were in use by the microorganisms within the sludge. After DO was below $1 \mathrm{mg} / \mathrm{L}$ and $\mathrm{NO}_{3}$ was below 0.6 $\mathrm{mg} / \mathrm{L}, \mathrm{TP}$ and Fe release was observed (Figure 3a). The redox potential in the reactors at that point was $-90 \mathrm{mV}$. Iron concentrations in the liquid increased from non-detectable to $4 \mathrm{mg} / \mathrm{L}$ by the end of the study. 
a)

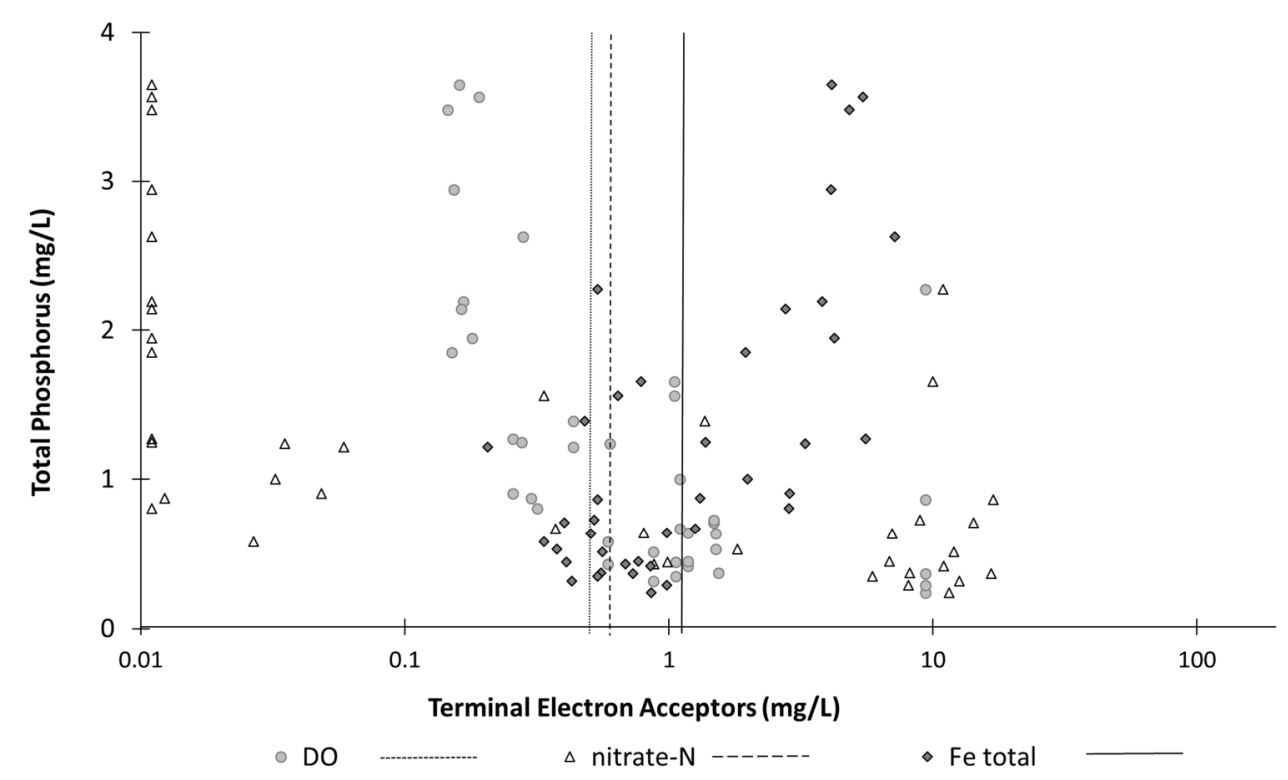

b)

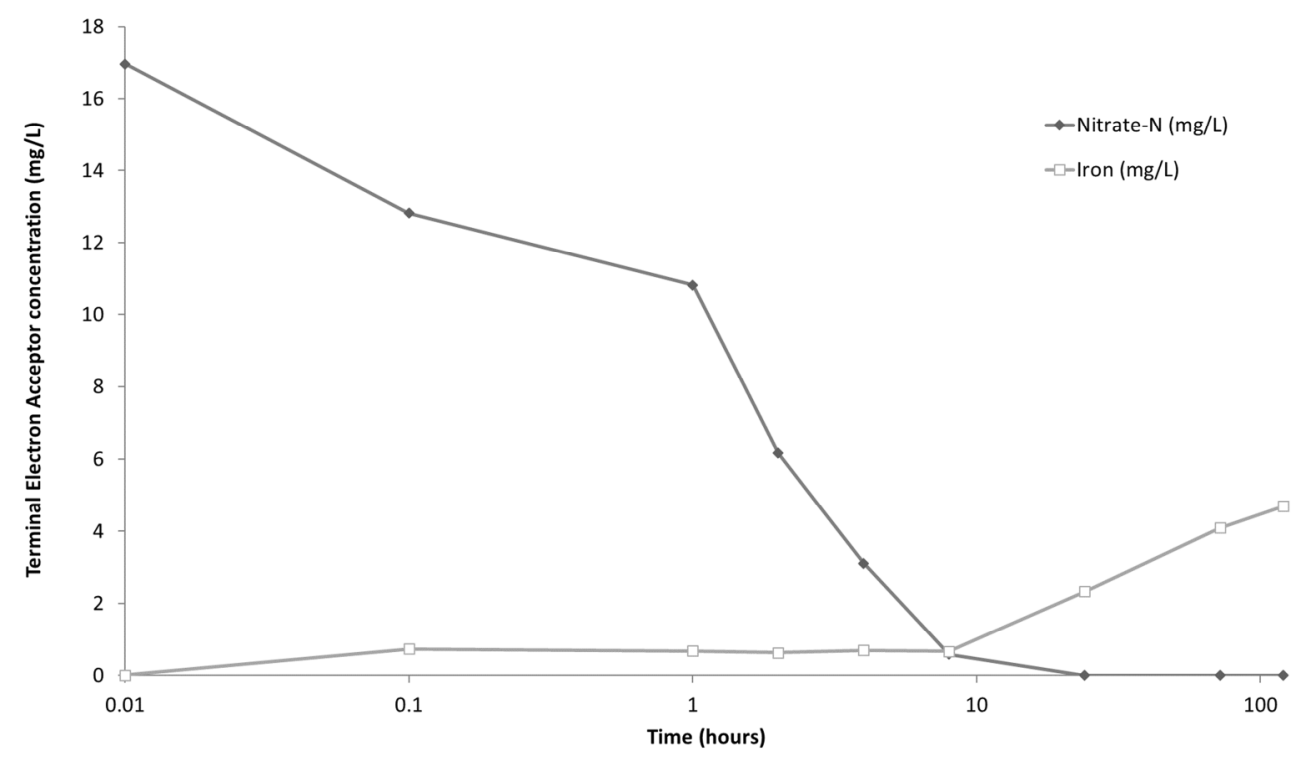

Figure 3. Dynamics of terminal electron acceptors under controlled conditions. a) Impact of $\mathrm{DO}, \mathrm{NO}_{3}$ and Fe availability on TP release, and b) Nitrate depletion and iron release dynamics.

Iron release from sludge proceeded at a slow rate in parallel with $\mathrm{DO}$ and $\mathrm{NO}_{3}$ utilisation. After $\mathrm{NO}_{3}$ dropped below $1 \mathrm{mg} / \mathrm{L}$, the rate of Fe release significantly increased (Figure 3b) suggesting preferential use of $\mathrm{DO}$ and $\mathrm{NO}_{3}$ as TEA over $\mathrm{Fe}$, in agreement with biogeochemistry literature (Reddy and DeLaune, 2008). This could be the result of Fe use by facultative microorganisms capable of switching pathways to use either TEA (Cooper et al., 2003) or by specialists 
microorganisms that can outcompete nitrate reducers once the environmental conditions (e.g., TEA abundance, length of exposure, electron donor abundance) are favourable (Ehrlich and Newmann, 2009). Indeed, a recent survey of Danish wetland systems reported the presence of Geobacter metallireducens, an organism capable of using either $\mathrm{NO}_{3}$ or Fe as TEA, in horizontal flow CWs treating domestic wastewater (Adrados et al., 2014). Whilst it is unclear which factors most influenced TEA use in this study, it would appear the (relative) abundance of TEA is a critical factor that can result in TP release.

The concentrations of effluent nitrate observed in the field when TP release was detected, however, were much higher than those observed under the controlled laboratory conditions, at $7 \mathrm{mg} \mathrm{NO}{ }_{3}-\mathrm{N} / \mathrm{L}$ for the anoxic site and $0.6 \mathrm{mg} \mathrm{NO}_{3}-\mathrm{N} / \mathrm{L}$ for the test reactors. This suggests that absolute numeric values for measurable parameters such as redox, $\mathrm{DO}$ and $\mathrm{NO}_{3}$ bulk water concentrations may not be sufficient to understand or, indeed, predict TP cycling in wetland environments. Similar behaviour has been observed in impacted lakes, where P release from sediments under quiescent and anoxic conditions results in internal eutrophication (Smolders et al., 2006). Results from this study suggest local environments could be generated within the sludge-water system where the mass transfer rate of $\mathrm{DO}$ and $\mathrm{NO}_{3}$ into the sludge layer is, in fact, the limiting step for Fe and associated TP release. This hypothesis was tested by isolating the contribution of convection and diffusion processes in the system of interest. 
Impact of convection and diffusion

There was no impact on DO concentrations in the reactors as a result of the mixing applied, with both the dynamic and the static reactors showing a similar pattern of DO depletion within the first four hours of experimentation as in the concentration gradient studies. Phosphorus concentrations in the bulk liquid were well-matched in static and dynamic reactors, suggesting convection had no impact on transformation rates for TP (Figure 4). Iron profiles were more scattered than TP, with two samples having significantly higher TP concentrations in the dynamic reactors, reflecting a positive impact of convection on those samples.

a)

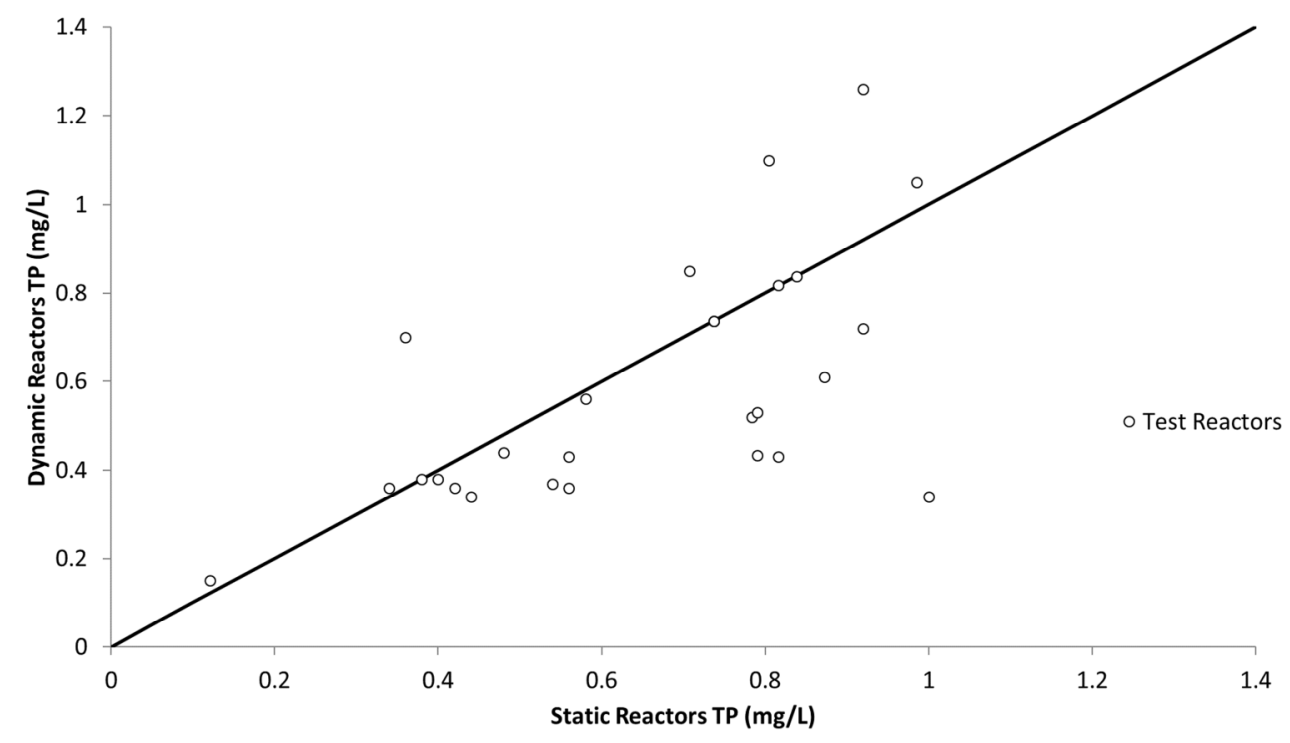

b)

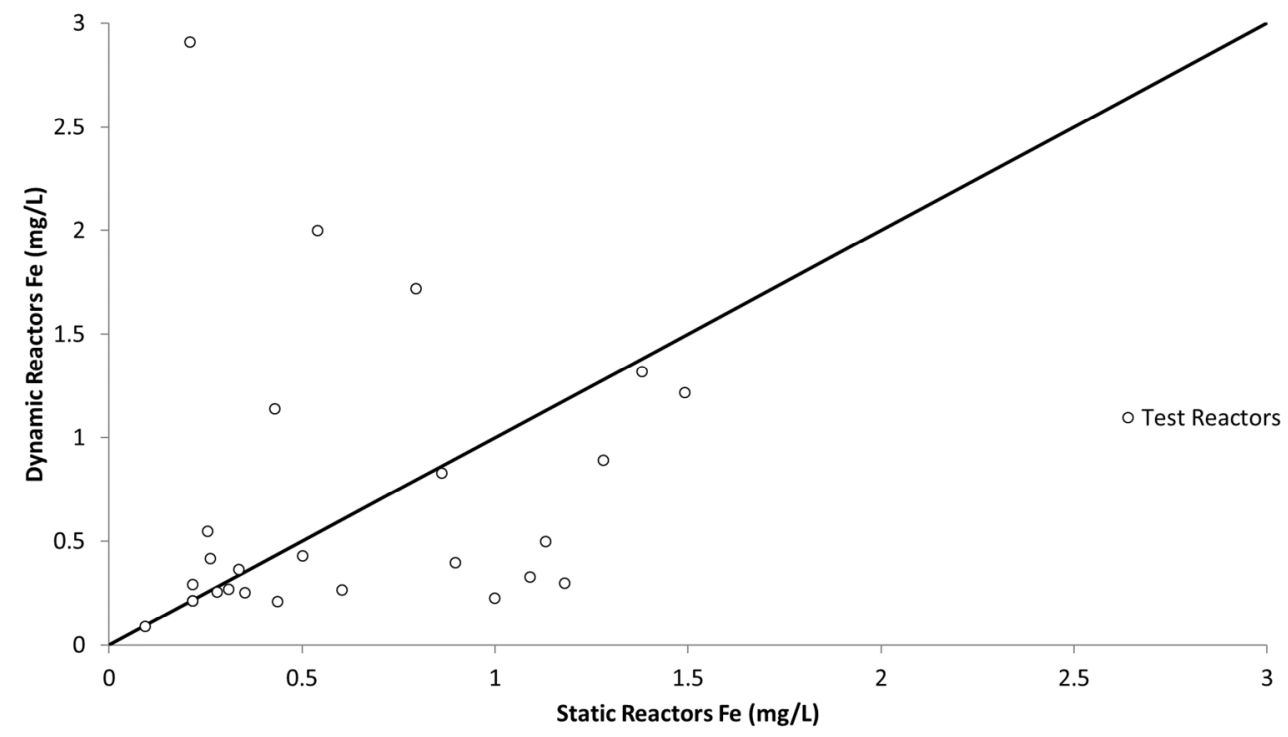


c)

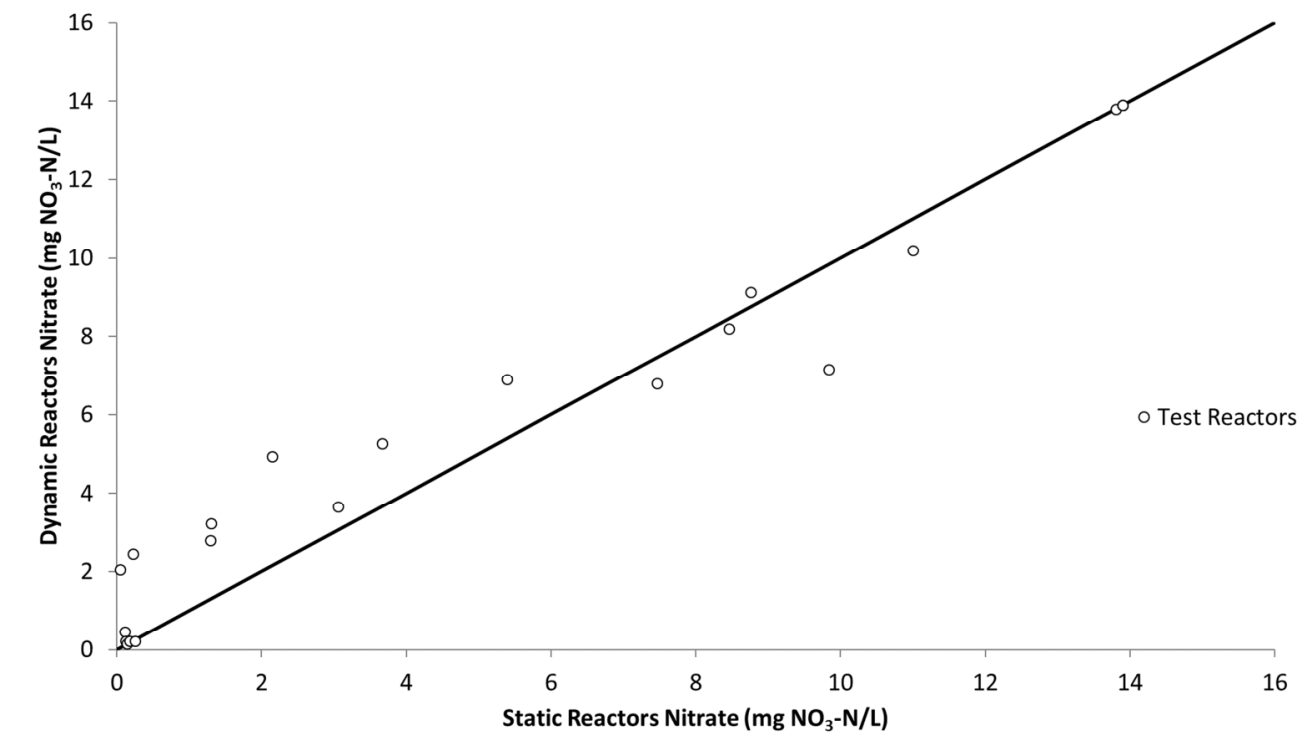

Figure 4. Changes of a) total phosphorus, b) total iron and c) nitrate, under dynamic and test conditions. The parity line represents a scenario of no difference between static and dynamic conditions.

The test conditions in this study were a 50:50 (by volume) sludge to water ratio. In sludge storage tanks, this ratio can vary widely, from site to site and within the same site, depending on operational (emptying) practices. In TWs, sludge can accumulate both within the bed matrix and on the surface of the bed depending on feeding strategies and length of operation (Knowles et al., 2011), with surface sludge accumulation in Fe-dosed systems ranging from a few millimetres to $12 \mathrm{~cm}$ (Dotro et al., 2015). As such, stratification of solids (sludge) and bulk water pollutant concentrations can be significant, and further influence the rate of diffusion into the sludge and the associated risk of $\mathrm{P}$ and Fe release.

Phosphorus release risk mitigation in small wastewater treatment plants

This study has shown P release to be associated with both concentration gradients and the biogeochemical conditions under which sludge is stored. The former takes place when 
otherwise well-performing systems delivering final effluent TP concentrations below $1 \mathrm{mg} / \mathrm{L}$ suddenly receives a spike of TP in the influent. Under stable operating conditions (e.g., loadproportional Fe dosing) these instances should be rare, occurring only when upstream processes are upset such as during emptying of sludge holding tanks or inadequate desludging frequencies of settling tanks. Onsite sludge holding tanks typically have retention times much greater than 24 hours, and are known to mobilise pollutants into the water phase. On desludging, these liquors are typically fed back to the head of the works, increasing the influent pollutant load (Buzier et al., 2006). Mitigation of release risks associated with concentration gradients could therefore target these specific practices, either by tankering both water and sludge, flow balancing, aeration of the return liquor (e.g., introducing a cascade structure), or gentle aeration of the sludge holding tank. The latter would minimise TP release and, as a side benefit, reduce fugitive greenhouse gas emissions (Cruddas et al., 2014). Minimum levels of aeration and the costs associated with installing and operating such a system would need to be compared against the benchmark of temporarily increasing chemical dosing.

Mitigation of release risks associated with biogeochemical transformations within the wetland itself is more complex. The relative TEA abundance in the bulk water and their penetration into the sludge layer are likely to be controlling factors for Fe biochemical cycling and the associated $\mathrm{P}$ release. The discrepancy in trigger values for $\mathrm{P}$ release in the field and the controlled experiments suggests monitoring of $\mathrm{DO}$ and $\mathrm{NO}_{3}$ absolute numeric values is unlikely to negate the $\mathrm{P}$ release risk. Forced aeration of HF wetlands as currently employed in the UK results in bulk water DO levels above $5 \mathrm{mg} / \mathrm{L}$ (Butterworth et al., 2016b) . Whilst sludge DO in the field has not been measured, under these conditions, it is expected to remain aerobic and as such inhibit Fe and associated $\mathrm{P}$ release due to microbial use of Fe as TEA. Current aeration of HF wetlands is above the thresholds needed for ammonia removal targets, equivalent to 
activated sludge WWTPs requirements on a PE basis (Butterworth et al., 2016a), thus efforts are being made to provide better guidance to enable aeration savings in terms of both carbon emissions and financial costs (Butterworth, 2014). Based on the findings from the present study, ensuring DO saturation in the water is currently the preferred strategy for promoting oxygen penetration into the sludge layer. This strategy should be compared against pro-active management of the conventional (zero energy, anoxic) HF wetlands based on a better understanding of sludge-water interactions. A model for TEA utilisation under the conditions expected in WWTPs is needed for better understanding of Fe and P dynamics. For the model to be of practical use for risk mitigation, it should consider sludge thickness, Fe form, organic matter content and degradability, the type of microorganisms that develop within the sludge, and the relative TEA abundance.

\section{CONCLUSIONS}

Iron dosing for the removal of phosphorus in domestic WWTPs is effective but with sludge storage times typically greater than 24 hours and limited $\mathrm{DO}$ and $\mathrm{NO}_{3}$ concentrations, there is a risk of release of TP. The rate of release increased with increasing water-sludge $P$ concentration gradients, although the impact of microbial competition and sludge characteristics on the diffusivity of the individual TEAs into and from sludge is currently unknown. A better understanding of links between iron, phosphorus and nitrate cycling is needed to enable proactive mitigation strategies to be developed for small WWTPs.

\section{ACKNOWLEDGMENTS}

The authors would like to kindly acknowledge the financial support from Severn Trent Water for conducting this research. 


\section{REFERENCES}

American Public Health Association (APHA) (2005). Standard Methods for the Examination of Water and Wastewater (21st ed.)

Adrados, B., Sánchez, O., Arias, C. A., Becares, E., Garrido, L., Mas, J., Brix, H., and Morató, J. (2014) Microbial communities from different types of natural wastewater treatment systems: Vertical and horizontal flow constructed wetlands and biofilters. Water Research, 55, 304-312.

Brix, H. and Arias, C. A. (2005) The use of vertical flow constructed wetlands for on-site treatment of domestic wastewater: New Danish guidelines. Constructed wetlands for wastewater treatment, 25(5), 491-500.

Butterworth, E. (2014) The use of artificial aeration in horizontal sub-surface flow constructed wetlands for tertiary nitrification. PhD Thesis. Cranfield University, UK.

Butterworth, E., Dotro, G., Jones, M., Richards, A., Onunkwo, P., Narroway, Y., and Jefferson, B. (2013) Effect of artificial aeration on tertiary nitrification in a full-scale subsurface horizontal flow constructed wetland. Ecological Engineering, 54, 236-244.

Butterworth, E., Richards, A., Jones, M., Dotro, G., and Jefferson, B. (2016a) Assessing the potential for tertiary nitrification in sub-surface flow constructed wetlands. Environmental Technology Reviews, 5(1), 58-77.

Butterworth, E., Richards, A., Jones, M., Mansi, G., Ranieri, E., Dotro, G., and Jefferson, B. (2016b) Performance of Four Full-Scale Artificially Aerated Horizontal Flow Constructed Wetlands for Domestic Wastewater Treatment. Water, 8(9), 365.

Buzier, R., Tusseau-Vuillemin, M. H., dit Meriadec, C. M., Rousselot, O., and Mouchel, J. M. (2006) Trace metal speciation and fluxes within a major French wastewater treatment 
plant: Impact of the successive treatments stages. Chemosphere, 65(11), 2419-2426.

Cooper, D. C., Picardal, F. W., Schimmelmann, A., and Coby, A. J. (2003) Chemical and Biological Interactions during Nitrate and Goethite Reduction by Shewanella putrefaciens 200. Applied and Environmental Microbiology, 69(6), 3517-3525.

Cruddas, P. H., Wang, K., Best, D., Jefferson, B., Cartmell, E., Parker, A., and McAdam, E. J. (2014) Diagnosis of an anaerobic pond treating temperate domestic wastewater: An alternative sludge strategy for small works. Ecological Engineering, 63(2014), 64-71.

Dotro, G., Fort, R., Barak, J., Jones, M., Vale, P., and Jefferson, B. (2015) Long-term performance of constructed wetlands with chemical dosing for phosphorus removal. In J. Vymazal (ed.), The Role of Natural and constructed wetlands in nutrient cycling and retention on the landscape. Springer International Publishing, 273-292.

Dotro, G., Jefferson, B., Jones, M., Vale, P., Cartmell, E., and Stephenson, T. (2011) A review of the impact and potential of intermittent aeration on continuous flow nitrifying activated sludge. Environmental Technology, 32(15), 1685-1697.

Ehrlich, H. L. and Newmann, D. K. (2009) Geomicrobiology of Iron. In Geomicrobiology. CRC Press, 279-345.

Headley, T. R., Huett, D. O., and Davison, L. (2003) Seasonal variation in phosphorus removal processes within reed beds--mass balance investigations. Water science and technology, 48(5), 59-66.

Kim, B., Gautier, M., Molle, P., Michel, P., and Gourdon, R. (2015) Influence of the water saturation level on phosphorus retention and treatment performances of vertical flow constructed wetland combined with trickling filter and $\mathrm{FeCl} 3$ injection. Ecological Engineering, 80, 53-61.

Knowles, P., Dotro, G., Nivala, J., and García, J. (2011) Clogging in subsurface-flow treatment 
wetlands: Occurrence and contributing factors. Ecological Engineering, 37(2), 99-112.

Lauschmann, R. E., Lechner, M., Ertl, T., and Langergraber, G. (2013) Experiences with preprecipitation of phosphorus in a vertical flow constructed wetland in Austria. Water Science and Technology, 67(10), 2337-2341.

Neal, C., Jarvie, H. P., Withers, P. J. a, Whitton, B. a, and Neal, M. (2010) The strategic significance of wastewater sources to pollutant phosphorus levels in English rivers and to environmental management for rural, agricultural and urban catchments. The Science of the total environment, 408(7), 1485-500.

Prigent, S., Paing, J., Andres, Y., and Chazarenc, F. (2013) Effects of a saturated layer and recirculation on nitrogen treatment performances of a single stage Vertical Flow Constructed Wetland (VFCW). Water Science and Technology, 68(7), 1461-1467.

Reddy, K. R. and DeLaune, R. D. (2008) Biogeochemistry of Wetlands: Science and Applications, CRC Press.

Smolders, a. J. P., Lamers, L. P. M., Lucassen, E. C. H. E. T., Van Der Velde, G., and Roelofs, J. G. M. (2006) Internal eutrophication: How it works and what to do about it - a review. Chemistry and Ecology, 22(2), 93-111.

Thistleton, J., Berry, T., Pearce, P., and Parsons, S. (2002) Mechanisms of chemical phosphorus removal II: Iron(III) salts. Process Safety and Environmental Protection, 80(5), 265-269. 


\section{Supplementary Information}

Table S1. Summary of treatment works performance

\begin{tabular}{lcccc}
\hline \multicolumn{1}{c}{ Measurement } & \multicolumn{3}{c}{ Site } \\
& \multicolumn{2}{c}{ Anoxic } & \multicolumn{2}{c}{ Aerated } \\
\hline Sampling point & CW influent & CW effluent & CW influent & CW effluent \\
\hline Average daily flow $(\mathrm{L} / \mathrm{s})$ & \multicolumn{3}{c}{0.84} & \multicolumn{3}{c}{0.77} \\
Wastewater temperature $\left({ }^{\circ} \mathrm{C}\right)$ & 18.9 & 18.5 & 16.5 & 13.6 \\
$\mathrm{pH}$ & 8.0 & 7.9 & 6.6 & 7.0 \\
$\mathrm{DO}(\mathrm{mg} / \mathrm{L})$ & 3.4 & 4.9 & 4.1 & 9.2 \\
$\mathrm{COD}(\mathrm{mg} / \mathrm{L})$ & 29 & 20 & 66 & 22 \\
$\mathrm{TSS}(\mathrm{mg} / \mathrm{L})$ & 10 & 7 & 37 & 4 \\
$\mathrm{NO}_{3}-\mathrm{N}(\mathrm{mg} / \mathrm{L})$ & 16.7 & 7.15 & 28.0 & 34.1 \\
$\mathrm{NH}_{4}-\mathrm{N}(\mathrm{mg} / \mathrm{L})$ & 1.15 & 0.65 & 8.37 & 0.18 \\
$\mathrm{SO}{ }_{4}(\mathrm{mg} / \mathrm{L})$ & 146 & 141 & 133 & 118 \\
$\mathrm{Total}^{\mathrm{P}}(\mathrm{mg} / \mathrm{L})$ & 2.02 & 1.74 & 2.45 & 0.66 \\
$\mathrm{PO}_{4}-\mathrm{P}(\mathrm{mg} / \mathrm{L})$ & 1.31 & 1.26 & 2.02 & 0.56 \\
$\mathrm{Fe} \mathrm{total}(\mathrm{mg} / \mathrm{L})$ & 0.57 & 0.44 & 2.13 & 0.50 \\
$\mathrm{Fe}(\mathrm{III})(\mathrm{mg} / \mathrm{L})$ & 0.07 & 0.05 & 0.29 & 0.15 \\
$\mathrm{Fe}(\mathrm{IIII})(\mathrm{mg} / \mathrm{L})$ & 0.50 & 0.39 & 1.84 & 0.35 \\
\hline
\end{tabular}

